\title{
Russian language as a means of cross-border education development
}

\author{
Galina Marchenko ${ }^{1,}$, Kseniya Vodopyanova $^{2}$, Sergey Timofeev $^{2}$ and Sergey Maximets ${ }^{2}$ \\ ${ }^{1}$ Don State Technical University, 1 Gagarin sq., Rostov-on-Don, Russia \\ ${ }^{2}$ Donetsk National University, Russia
}

\begin{abstract}
The article deals with the issue of reducing the importance of the Russian language in the world. Culture is the total social experience of humanity, and language is a means of accumulating, storing, and transmitting this social experience, scientific and everyday information. It is a means of objectifying human consciousness, the continuity of generations, and their historical experience. Until 1991, Russian was the universal means of interethnic communication on one-sixth of the land. The refusal to learn the Russian language in some post-Soviet republics has led to a decline and even to a drop in the level of education and culture in general. The research aims to analyze the Russian language position as the core of culture and education in the post-Soviet space as a means of cross-border cooperation, development of education, and dialogue of cultures. The study has been conducted for 10 years in the South-East of Ukraine. It seems to us that the language situation in the Donbas can be projected with some degree of similarity to the entire post-Soviet space. To determine the principle of the state language policy of the post-Soviet republics, we used the analysis of Ukraine's legal documents in the period from 1991 to 2020. The presence of a common cultural space and language will help preserve peace and prevent war on the Eurasian continent. The common language space contributes to the development of economic, social, educational, and as a result of geopolitical ties.
\end{abstract}

\section{Introduction}

Today, fundamental changes are taking place in the world order: the unipolar world is being replaced by a multipolar one, and the USA hegemony has been seriously pushed by China and Russia. Western politicians constantly try to change the situation in the world after World War II. A wide variety of tools are used for this purpose: from sanctions under farfetched pretexts to outright lies and hacker attacks aimed at weakening and destroying Russia as a sovereign, strong, independent state and plundering its wealth. Since 1991, external players have made numerous attempts to withdraw post-Soviet countries from the field of the Russian world. Georgia, Moldova, Ukraine, and today Belarus are prime examples of this. The tools for implementing the plans of the collective West are silencing historical facts, erasing historical truth, and also technologies for destroying the Russian-speaking space.

\footnotetext{
*Corresponding author: donpedagog2020@yandex.ru
} 
Language is one of the most important forms of social consciousness, the mastery of which is a significant prerequisite for the development of other forms that are objective components of culture: everyday consciousness, political ideology, philosophy, law, morality, science, art, religion.

Language is the primary means of cultural preservation, broadcasting, and development.

From the pedagogical point of view, the most interesting thing for our research is the understanding that culture is, in fact, the total social experience of humanity, accumulated by it in the process of historical development.

Language is the means of accumulating, storing, and transmitting of this social experience, of this scientific and everyday information. Language is a means of thinking, learning about the world around you and yourself in this world, of expressing a person's attitude to themselves, to people, to values, to nature, to activities, and of communication with other people. It is a means of the human consciousness objectifying, the continuity of generations and their historical experience, cultural codes, norms, and traditions $[1,2]$.

In the most general form, all abovementioned defines the purpose of education, where the Russian language is the most important means of its functions implementing.

The current socio-cultural and political situation has developed in such a way that the Russian people are the most divided people on our planet by various barriers and borders. Until 1991, one-sixth of the land area was inhabited by representatives of different peoples and nationalities within the borders of a single state entity, where the Russian language was the universal means of interethnic communication. Russian language skills have opened up wide opportunities for anyone to learn not only about the thousand-year-old Russian culture but also about the world culture treasury. And this, in turn, provided a high level of education and general culture for all citizens of a great country. The refusal to learn the Russian language in some post-Soviet republics has led to a decline and even to a drop in the level of education and culture in general $[3,4]$. This conclusion can be made based on the social networks content analysis, the speeches of participants in various discussions on Russian television, who came from the former Soviet republics.

The purpose of our research is to analyze the Russian language position as the cultural and educational core in the post-Soviet space as a means of cross-border cooperation, education development, and dialogue of cultures.

\section{Materials and methods}

The study was conducted over a decade in the South-East of Ukraine, as the language situation in the Donbas can be projected with more or less similarity to the entire post-Soviet space where Russian was used as a means of interethnic communication.

It was the Russian language that served as a tool for implementing the two main features of Russian education - universality, and fundamentality, which contributed to the formation of a qualified specialist for industrial and agricultural production, for science, economics, culture, and education.

Throughout the twentieth century, the Russian language and the languages of the USSR peoples peacefully coexisted, interacted, mutually influencing each other and enriching themselves.

To determine the basis of the post-Soviet republics' state language policy, the Ukraine legal documents analysis was used. Thus, in Article 10 of Ukraine's Constitution of 1996, it was stated that "In Ukraine, the free development, use, and protection of Russian is guaranteed, ... The state promotes the study of languages of international communication..." [5]. Survey data analysis on the language usage by the Ukraine population conducted by various agencies and services in the early 2000s, in particular, by the well-known Gallup 
Institute, showed that $80 \%$ of Ukrainian citizens considered Russian to be their native language, and they spoke it (Fig. 1).

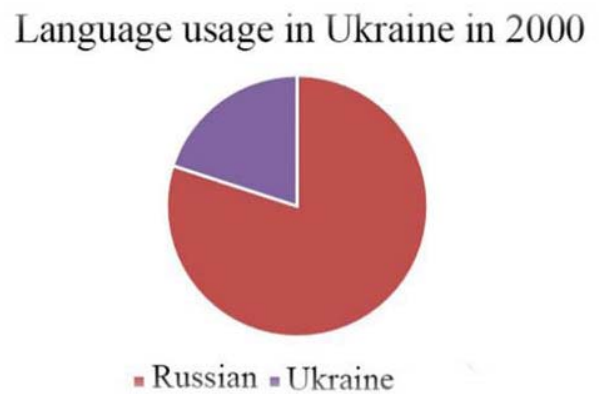

Fig. 1. Language usage in Ukraine in 2020.

\section{Results}

Analysis of Google Trends, and Yandex and VKontakte data shows that in the XXI century's first decade, 68\% of Western Ukraine's residents and 94\% in the East preferred Russian [6]. The analysis of the survey results obtained by Gallup service in 2008 confirms these data (83\%), as well as Wikipedia data, where $60 \%$ of edits and $70 \%$ of views were also in Russian [7].

Observations and surveys of Donetsk universities' teachers and students show that almost everyone the authors met and communicated with used only Russian at home, at work, on the street, and in transport.

\section{Discussion}

The native language study occupied a special place in the pedagogical concepts of the classics of pedagogical science such as V. Ratke, J. Komensky, K. Ushinsky. Showed in his "Memorial" work V. Ratke's ideas about the native language learning priority at the initial education stage were advanced for that time (XVI century), but they continue to remain relevant today. He argued that the mother tongue in primary school should be the language of all other school subjects. At the same time, we must remember that before him, the education language continued to be Latin, incomprehensible to the absolute majority of children. Defending the idea of the native language learning importance, V. Ratke also proposed an original method of the native language and reading teaching, emphasizing the native language role in the German lands' consolidation, in the national education system formation [8].

V. Ratke's ideas were taken up and fundamentally developed by J. A. Komensky in his numerous scientific and pedagogical works "Treasury of the Czech Language", "The Great Didactic", "Pansophiæ Prodromus", "On the Culture of Natural Talents", "An Open Door to Languages", etc. [9] Putting forward the extremely complex and important task, given in his work "De rerum humanarum emen-datione consultatio catholica", of improving people, the primary means of this outstanding teacher considered "pansophic" education and raising the general cultural level. He called the basis for its mastering the native language studying and the language culture formation. According to J. Komensky, the native language was considered as a means of personal development, allowing to overcome the scholastic approach to teaching, meaningless memorization of educational material by heart, which was inherent in the medieval school. 
According to the pedagogical views of J. Komensky, the native language was a means of human knowledge of the world and oneself in the world, a means of learning, a means of transmitting knowledge and information. The teacher tried to prove and convince others that there is a close relationship between language, thinking, and the real world, on the one hand, and between the native language and the intellectual and spiritual and moral development of the child, on the other [10].

These thoughts are confirmed by modern scientific data [11].

K. D. Ushinsky is considered to be a teacher of Russian teachers [12] . In his pedagogical heritage, a special place is occupied by the native language, the study of which he considered as the domestic education foundation. And "... to lead people's education in a straight and correct way, one must look ... at what Russia needs in its current state, which is by the course of its history, with the spirit and needs of its people..." [13]. The teacher warns politicians, public figures, and officials from education and teachers themselves from constant educational changes of various kinds that do not bring anything new to the educational process.

K. Ushinsky emphasized that "The modern significance of the people in the general historical life of mankind is one of the main sources not only of its external significance but also of its internal well-being. But only a conscious, reasonable training and a reasonable education can give speed to the people's development: they awaken the people's mind, give freedom to their consciousness and enrich it with knowledge..." if it is performed in their native language [13].

One of the most significant factors in the coup rejection by the Donetsk region's population in 2014 was the attempt to pass a law banning the Russian language, which was done in Ukraine quite recently. In K. D. Ushinsky we find a convincing justification for this Donbas residents' position: "...the language of the people is its integral organic creation, growing in all its national features from a single, mysterious, hidden grain somewhere in the depths of the national spirit. The people's language is the best, never fading and everblooming flower of its entire spiritual life, beginning far beyond the historical borders. ... the bright, transparent depths of the national language reflect not only the native country nature but also the entire history of the people's spiritual life .... the entire trace of their spiritual life is carefully preserved by the people in the folk word. Language is the most living, most abundant. and strong link that connects the obsolete, living, and future generations of the people into one great, historical living whole. It not only expresses the people's vitality, but it is this very life. ... as long as the people's language is alive in the people's mouth, so long the people are alive. And there is no violence more unbearable than that which wants to take away from the people the inheritance created by countless generations of their obsolete ancestors" [13].

When the mass Ukrainization in Donbas started since the 90 -ies of the last century, there was a widespread opinion among educators that an enforced study of the Ukrainian language to the native Russian language detriment was a means of "brainwashing" young people. It will cause a decrease in the level of literacy proficiency in the Russian literary language. Today we are reaping the fruits of this vicious policy because the real literacy rate has fallen catastrophically: young people do not know Russian very well, and they practically do not know Ukrainian. But the basis of a person's general culture and education is the native language. And it is difficult to argue with K. D. Ushinsky, who claimed that "...this amazing teacher - the native language - teaches not only a lot, but also teaches surprisingly easily, according to some unattainable facilitating method. By learning the native language, the child learns not only words, their additions, and modifications, but an infinite number of concepts, views on objects, a lot of thoughts, feelings, artistic images, logic, and philosophy of language — and learns easily and quickly... Such is this great national teacher — native word!" [13]. 
The teacher considered the native language study to be fundamentally important. Today, psycholinguistics has proved that only the native language, as an integral semantic system, is tuned to the human soul's inner strings - mind. The language spoken among adults is less important for a child's development than the language in which he is appealed, forcing the child to express his inner states. An actively implemented foreign language is always a sign system (dividing!), which introduces meaningless goals into thinking, suppresses, and clogs native language roots like a weed. These words of the great teacher clearly explain the position of Donbas in the language issue, which is why the ban on the Russian native language is an encroachment on the very existence of the people, which the Donetsk region's people cannot agree with [13].

Being an ardent supporter of the national education principle, the outstanding teacher argued that "Education should enlighten the man's mind, that a clear road for good lays before his eyes," and that "education, created by the people and based on a national basis, has the educational force, which is absent in the best systems, based on abstract ideas or borrowed from other people" [13].

Today, we can safely say that the "integration of Ukraine's education into the European and world space", which it so aspired to, has generally failed. But after all, the Donbas educational institutions also tried to draw in the Bologna system, which, under the slogans of "mobility of students and teachers", acted as a kind of tool that filtered out the most talented young people for the needs of multinational corporations. Today, the Donetsk region's education system refuses such "integration". Educational organizations see their future in cooperation with the education system of the Russian Federation, which was defended by K. D. Ushinsky two centuries ago. He wrote: "Public education, which strengthens and develops the nation in a person, while at the same time developing his mind and selfconsciousness, powerfully contributes to the development of national self-consciousness in general; it brings the light of consciousness into the recesses of the national character and has a strong and beneficial influence on the development of society, its language, its literature, its laws, in a word, on its entire history" [13]. And he continued: "As it is impossible to live according to another nation's model, as tempting as this model is, nor it can be brought under a foreign educational system, no matter how it is slender and well thought out. Every nation in this respect should try its strength" [13].

K. D. Ushinsky calls a characteristic feature of the folk school the education in students of the sacred beginning of the Motherland, love for the Fatherland, which "gives education the right key to the heart of a person and powerful support for the fight against his bad natural, personal, and ancestral inclinations." It is impossible not to agree with the idea of the teacher that "... patriotism is deeply rooted in our ... families, although it sleeps for some time to come and wakes up only after some strong push ... to spite ourselves, we are much more patriotic than we think, but there is also a lot of that innate Slavic flaw that carries us with foreignness beyond the limits of prudence" [13].

"It is to destroy this duality of our nature that education should primarily act" ... Only "a madman who does not have the slightest idea about the human soul, nor its moral dignity, nor its upbringing can think and try to prove that everything in our history is worthy of ridicule and contempt...". But "this does not mean to educate the soul, but rather to destroy it; it does not mean to fertilize nature, but rather to make it completely barren; no, this is not education, but savagery, vandalism, because only barbarians tend to have no history and destroy its most precious monuments, destroy everything and create nothing. And this truly vandal, destroying everything, saving nothing and creating nothing direction is often taken by many of us as a sign of higher European education..." [13]. The above fully describes the madness that has engulfed former Ukraine.

K. D. Ushinsky rightly foresaw and predicted the fate of such "patriots", which once again emphasizes his genius and the significance of his pedagogical heritage not only for teachers, 
educators, teaching staff but also for the entire nation, regardless of the professional activity scope.

Ignoring the historical and pedagogical experience of previous generations has led Ukraine to sorrowful consequences.

The first document adopted by the nationalists who came to power as a result of the coup was a law abolishing the use of Russian as a regional language, which was one of the reasons for the Crimea's separation and the civil war in the Donbas. By the beginning of 2011, only $9 \%$ of Russian schools remained in Ukraine, and this academic year they were destroyed. Russians in Ukraine have thus found themselves in the same discriminatory situation of linguicide as Russians in the Baltic States, who are second-class citizens there [14].

Russian was repealed as a regional language in Ukraine after the coup on February 21, 2014, which effectively removed the Russian language from the Ukrainian educational, cultural and information space. Further "law-making" by the Ukrainian authorities on language policy issues is aimed exclusively at discrimination and the Russian language displacement from almost all spheres of life and activity: education, science, culture, media, public service, art, etc.

Such a policy cannot contribute to the Donbas reunification with Ukraine, moreover, since today the LDPR has determined by law that the only state language is Russian. This is due to the lack of demand for the Ukrainian language in the Donbas and the psychological trauma that Ukraine inflicted on its citizens with its air and artillery attacks, destruction of infrastructure, and the deaths of children, women, the elder people, and soldiers.

The great German poet J. V. Goethe said that the number of languages you knew was equal to your personality. Ukraine, by banning the native Russian language, destroys not only every person but also society, education, culture, and country.

\section{Conclusions}

The reason for the choice of such a policy by the Ukrainian authorities has many aspects. The political reasons are the authorities' desire to retain their rights to govern the state, distracting the electorate's attention with language issues [15].

Economic aspects are related to making people aware of the language problem so that they do not interfere with the ongoing robbery of the people and the country.

The essence of the social aspects of the problem is that the education system introduction of the non-native language of the citizens' majority will inevitably lead to a decrease in the level of education and general culture. And the uneducated person is easier to manage, easier to deceive and to make him or her do what politicians need.

That is why Russian language policy should not be left out of the state's attention. These issues should not be allowed to take their course, so the changes that were made to the Constitution of the Russian Federation concerning the fact that for the first time, the Russian people and the Russian language are recognized as state-forming are very timely.

The presence of a common cultural space and language will help preserve peace and prevent war on the Eurasian continent. The common language space contributes to the development of economic, social, educational, and as a result of geopolitical ties.

Thus, we can say that cross-border cooperation can be carried out at three levels, through which the unifying consolidating function is implemented.

At the micro-level, the Russian language promotes mutual understanding between people, providing interpersonal communication.

The meso-level is the mediated interaction of regional and state scales, while the macrolevel is the level of communication between peoples and States.

The Russian language provides communication and interaction on all three levels, but where it is rejected as a language of international communication, there is misunderstanding 
and problems, division, and hostility. And we can't allow that to happen today. Therefore, we must protect, enrich, and develop our native "great and powerful" Russian language.

\section{References}

1. O. Fedotova, V. Latun, 6th International Conference Edu World 2014: Education Facing Contemporary World Issues 180, 61-65 (2015)

2. I.G. Aktamov, Nauchnyi Dialog 4, 221-237 (2020)

3. D. Teurtrie, Vestnik Sankt-Peterburgskogo Universiteta-Istoriya 6291, 43-56 (2017)

4. O.A. Zapeka, Zh.A. Beresneva, Vestnik Slavianskikh Kultur-Bulletin Of Slavic Cultures-Scientific and Informational Journal 54, 35-42 (2019)

5. The Constitution of Ukraine homepage, http://sevkrimrus.narod.ru/ZAKON/konstukr.htm

6. Google Trends data on Livejournal, https://romix1c.livejournal.com/70913.html

7. Gallup, "Russian Language Enjoying a Boost in Post-Soviet States" article http://www.gallup.com/poll/109228/Russian-Language-Enjoying-Boost-PostSovietStates.aspx

8. Memorial by $V$. Ratke http://www.vostlit.info/Texts/Dokumenty/Germany/XVII/16001620/Wolfgang_Ratke/memorial.phtml?id=5936

9. R.C. dos Santos, J.E. Souza, Revista Tempos E Espacos Educacao 11(1), 225-238 (2018) https://en.wikipedia.org/wiki/John_Amos_Comenius

10. M. Cerna, Czech Republic. Blended Learning: Educational Innovation For Personalized Learning ICBL 11546, 46-56 (2019)

11. L. Guseva, History Of Education \& Childrens Literature 13(1), 479-491

12. K.D. Ushinsky, Selected pedagogical works (Enlightenment, Moscow, 1968)

13. K.M. Vodopyanova, Bulletin of the peoples' friendship University of Russia. Series: Russian and foreign languages and methods of their teaching 4. 68-71 (2010)

14. K. Maksimovtsova, East European politics and societies 34(2), 375-399 (2020) 